\title{
The Census of Marine Life: goals, scope and strategy
}

\author{
KRISTEN YARINCIK AND RON O’DOR \\ Consortium for Oceanographic Research and Education, Suite 420, 1201 New York Ave. NW, Washington, DC 20005, \\ E-mail: kyarincik@coreocean.org
}

\begin{abstract}
SUMMARY: The Census of Marine Life aims to assess and explain the changing diversity, distribution, and abundance of marine species from the past to the present, and to project future ocean life. It assembles known historical data back to 1500 in an online Ocean Biogeographic Information System (OBIS) and has over 1000 scientists from 70 countries using advanced technologies to quantify and discover unknown life in under-explored ocean realms. Over 99\% of the 6 million records now in OBIS are from the top $1000 \mathrm{~m}$ of the water column, so the mid-waters and floor of the open ocean and the polar ice oceans are special targets. Even where the species are known, their distributions and abundance are largely speculative. This report outlines the strategies of COML projects to efficiently reveal the $95 \%$ of the biosphere beneath the waves, from microbes to whales. Open access to the OBIS data set will improve capacity to predict future impacts of climate and human activity. The baseline created by 2010 and the calibrated techniques developed will become important tools for monitoring and managing future ocean ecosystems to maintain their capacity to provide crucial services to our blue planet.
\end{abstract}

Keywords: oceans, species, biogeography, biohistory, diversity.

RESUMEN: El Censo de la Vida Marina: objetvos, Ámbito y estrategia. - El programa denominado Censo de la Vida Marina (Census of Marine Life - COML), tiene por objeto evaluar y explicar la diversidad, distribución y abundancia actual de las especies marinas, considerando también lo acontecido con la biodiversidad en el pasado y proyectándose hacia el futuro. Recopila datos históricos desde 1500 años atrás en un Sistema de Información Biogeográfico Oceánico (Ocean Biogeographic Information System - OBIS) y coordina a más de 1000 investigadores de 70 países, quienes utilizando tecnologías avanzadas cuantifican y descubren la vida desconocida de los dominios oceánicos menos explorados. Actualmente, más del 99\% de los 6 millones de registros en el OBIS provienen del 25\% de las áreas más someras de los océanos de manera que las aguas intermedias y el fondo del océano abierto, y los océanos congelados, constituyen blancos especiales de estudio para COML. Aun cuando las especies sean conocidas, el conocimiento que se tiene de sus distribuciones y abundancias puede todavía ser muy especulativo. Este informe presenta las estrategias de los proyectos del Programa COML para explorar eficientemente el $95 \%$ de la biosfera que yace bajo las olas, desde microorganismos hasta ballenas. El acceso abierto a los datos recogidos en OBIS, perfeccionarán la capacidad de predecir los futuros impactos del clima y de la actividad humana sobre la biodiversidad marina, su distribución y abundancia. La línea de base que se creará hacia el año 2010 y las técnicas calibradas que se desarrollen hacia esa fecha, constituirán importantes herramientas para la vigilancia y la gestión de los ecosistemas marinos para mantener su capacidad de proporcionar servicios cruciales a nuestro planeta azul.

Palabras clave: océanos, especies, biogeografía, biohistoria, diversidad.

\section{THE GOAL, SCOPE, AND STRATEGY OF THE CENSUS OF MARINE LIFE}

Evaluation of reports of crowded shorelines, oceanic pollution, and exhausted fisheries as well as more than a billion cubic kilometers of unexplored water requires a systematic, global census of marine life. Only an encompassing census can probe whether the reports reveal regional declines or global changes, and the extent of our ignorance. Fortunately, archives spanning centuries, technologies empowering exploration, and communications 
connecting scientists make such a global undertaking feasible. Accordingly, in the year 2000 the Census of Marine Life (COML) began under the leadership of an International Scientific Steering Committee (SSC) now encompassing nations on five continents.

Censusing many trillions of moving organisms belonging to millions of diverse species in the threedimensional oceans of the world challenges marine scientists. To cope with this challenge, the SSC defined a goal for the Census, sharply. It set a scope for the work. It devised a strategy. This article updates Decker and O'Dor (2002).

Goal: Assess and explain the changing diversity, distribution, and abundance of marine species, from the past to the present, and project future marine life. Going beyond a search for unknown species to being a census, the Census of Marine Life encompasses the diversity of species as well as their abundance and geographic distribution.

Scope: Consider global marine life since fishing became important, typically about the year 1500 , and some decades into the future. The scope encompasses realms from icy polar to warm tropical waters and from tidal zones shared by humans down to dark trenches 11,000 meters deep. The scope encompasses microscopic plankton in the light and sea lions plunging beneath, down to worms in abyssal sediments. It encompasses organisms that shift on the slopes of seamounts and others that tolerate fiery oceanic vents.

Strategy: For the world's few thousand marine scientists to progress beyond exploration to a global census requires wise strategies, or else decades could pass while interesting work falls short of the cumulative progress possible. The SCC devised the following strategies.

\section{FOCUSING ON THE KNOWABLE UNKNOWN}

Explorers selecting strategies for discovery reason which paths have the highest probability of success. Nature will make the final selection between open avenues and blind alleys, but distinguishing among known, unknown, and unknowable is a basic pre-selection filter. The known is easiest to filter out. Stone tablets, libraries, and now the electronic web have accumulated a vast inventory of the known. A standard scientific report first reviews literature to draw a baseline of the known and to pre-select against its re-exploration.

Filtering unknowable from unknown is harder. The profit of avoiding fool's errands and focusing instead on the knowable unknown justifies the hard reasoning. Some hard reasoning concerns the causes of unknowability because too fine a filter might preselect against great discovery. Still some things are intrinsically unknowable, the weather weeks hence and the exact number of fish in a bay a decade from now. Such intrinsically unknowable things seem safe to filter out.

Some things are unknowable because search is impractical. For example, a sea to be explored is inaccessible, specimens explode, or otherwise deteriorate, when brought to the surface, or cost and tedium overwhelm. Because boundaries of practicality between the unknown and the unknowable can be breached, as by submarines and highthroughput DNA analysis, the filter for removing the practically unknowable must be revised frequently and kept up to date.

Opportunity for the Census lies in the knowable unknown. To begin concentrating effort there by establishing the known, the SSC examined the known (O'Dor, 2003, 2004). After reasoning, the SSC focused on the tasks and projects described below to investigate the knowable and enlarge the known. What is unknowable must be reviewed as we advance, but it is an unreasonable basis for a research strategy.

TEN-YEAR LIFE, 2000-2010

Limiting lifetimes concentrates minds. Accordingly and strategically, the SSC fixed the life of the Census as 2000-2010, the first decade of the millennium.

\section{SIX REALMS}

A census of the life in the vast oceans begins with a strategic division into parts that can be grasped. Freely flowing currents render division among bordering nations or even among oceans illogical. On the other hand, dividing exploration among the six realms and subsidiary zones diagrammed in Figure 1 makes strategic sense. The realms and zones are practical as they correspond 


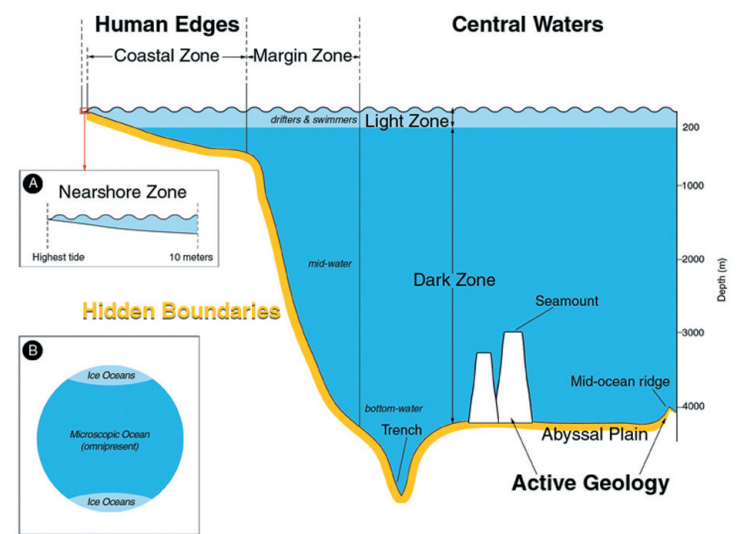

FIG. 1. - An ocean basin cross section illustrating the realms and zones of the world oceans as defined by the Census of Marine Life. The insets depict (A) the Nearshore Zone of the Human Edges and (B) the realms of Ice Oceans and the omnipresent Microscopic Ocean (O’Dor, 2003).

to the difficulty and technology of their exploration. The realms and zones make biological sense as light, pressure and temperature confine species to a few realms or zones. Admittedly, the realm of the Microscopic Ocean, unbound by environmental parameters, crosscuts the other five, but unique molecular tools are required to tackle the overwhelming presence of little understood microbes in the ocean.

The six realms and subsidiary zones named in Table 1 encompass all life from the surface of the nearshore to the bottom of the deep ocean. The realms and zones help reveal the diversity, distribution, and abundance of marine life. In the nearshore zone and on continental shelves and slopes, fish, shellfish, and lobster abound. In the light zone of the ocean's central water, drifting microbes photosynthesize food that miniature shrimp and swimming fish eat. In the dark of central water, jellyfish swarm, and in the sediment snowed from above onto the abyssal plain, microbes and worms prosper. Around active seafloor vents, heat-resistant microbes survive. In polar oceans, algae photosynthesize inside the sea ice. The small, drifting organisms that photosynthesize all the primary food make up almost all the 145,000 million tons of marine biomass. Small animals like krill account for most of the animal mass, while prominent large animals, like fish and whales, constitute only a small crucial percentage. In all oceanic realms, finding and naming species of animals show unflagging progress as well as opportunity.

\section{THREE TASKS}

The scope of global marine life from the year 1500 into the future requires strategic division into eras and corresponding tasks. The SSC chose the tasks of answering three big questions. What did live in the oceans? What lives in the oceans now? What will live in the oceans of the future?

\section{The History of Marine Animal Populations (HMAP)}

History in the form of past trends of oceanic environment, human harvest, and marine life can give a head start to perceiving trends through the present into the future. So an important strategy is mining the archives of biology to the limits of recorded history, typically around the year 1500 . HMAP pursues the goal of extending time series with historical data to clarify the dynamic interplay of human and natural factors in the changes in commercial marine life and thus improve prediction by mathematical models of economics and oceanography as well as biology.

Historical data divides itself into periods. First and nearest to the present, many nations have col-

TABLE 1. - Six ocean realms distinguished environmentally and by the techniques and difficulty of their exploration. Some are divided into zones. Although vastness alone challenges explorers in some realms, all present challenging unknowns for discovery.

\begin{tabular}{|c|c|c|c|}
\hline Realm & Zone Area & $\%$ & Crucial Unknowns \\
\hline \multirow[t]{2}{*}{ Human edges } & Nearshore & 2 & Distribution \\
\hline & Coastal & 10 & Abundance \\
\hline \multirow[t]{2}{*}{ Hidden boundaries } & Margins & 7 & Species \\
\hline & Abyssal plains & 84 & Species \\
\hline \multirow[t]{4}{*}{ Central waters } & Light Drifters & 90 & Distribution \\
\hline & Swimmers & 90 & Distribution \\
\hline & Dark Mid-water & 90 & Species \\
\hline & Bottom-water & 90 & Species \\
\hline Active geology & & 2 & Species, distribution \\
\hline Ice oceans & & 7 & Species, distribution \\
\hline Microscopic ocean & & 100 & Species \\
\hline
\end{tabular}


lected fishery records since roughly 1900 , the "statistical" period. These data are generally printed, and scientists are increasingly using them to examine multi-decadal changes during the twentieth century. The data, however, generally need validation because their collection differs from country to country and from decade to decade.

Second, archival material, chiefly in the port and customs archives of European, American and colonial states, survives from 1850 to 1900, the "protostatistical" period. These materials can be compared with, and integrated into, the published data of the statistical period to extend measures of fish stocks back to the mid nineteenth century.

Third, data are scarcer and more difficult to interpret for the "historical" period before 1850. Yet some historians have devised indices of catch and fishing effort that can be aligned with records from the protostatistical and statistical periods to yield evidence of long-term changes in marine ecosystems. Finally, natural "archives" in fossils and sediments constitute the data for the paleoecological period. Methods for reliably determining ages and thus consistency between parallel samples are needed. Nevertheless some reliable time series, especially of clupeid and anadromous species, have been developed from 1500 to the present.

The strategy for using the archival data begins with the development of estimates or indices of catches and fishing effort in major commercial fisheries over the period 1500-2000. It includes using, for example, annual reports of fishery leases to derive more refined measures of catches and fishing effort in a few highly regulated, high-priced inshore finfish and shellfish fisheries from 1750 onwards. It also includes projecting back the known catch statistics of the protostatistical period (1850-1900) to test indices from the historical period.

Three centers make up HMAP. With support from the Danish Research Councils, the center at the University of Southern Denmark is responsible for coordination among researchers and students from more than 18 countries and a range of disciplines. The center at the University of Hull (UK) manages HMAP data. Much of the historical data assembled by the case study research teams has been rendered accessible in a common format that makes diverse data a coherent whole available online. The center at the University of New Hampshire (USA) encompasses the Departments of Natural Resources and of History and has taken a leading role in analytical methods and modeling.
A regional project strategy gives focus to HMAP. The regions include the South West African Shelf; Caribbean Sea; Gulf of Maine, Newfoundland and Grand Banks (North West Atlantic); North and Baltic Seas; White and Barents Seas; South East Australian Shelf; New Zealand (South West Pacific); Mediterranean Sea; South East Asia; and World Wide Whaling. The steering group for the Baltic and North seas exemplifies coordination with 22 members from Russia to England. It identifies historical data and develops fisheries and maritime history in seas that have traditionally contributed to the cultures and economies of their surrounding countries. Written records and archaeology show fishing along these coasts since well before the Middle Ages.

An analysis of marine life in the Baltic Sea and the Skagerrak since 1200 AD exemplifies HMAP projects in the Human Edges realm. Early fisheries appear driven by climate, but during the twentieth century when more data were available, changes in cod, sprat, herring, seals, and porpoises as well as environment defied a simple assignment of blame to climate, fishing, predation or pollution.

\section{Ocean Realm Field Projects}

The link between what lived and what will live in the oceans is "What lives in the oceans now?", the question to be answered by field projects exploring the ocean realms and zones (Table 1). In each realm and zone, one or more projects develops and then implements oceanic exploration. National and regional implementation committees broaden the projects' coverage of realms by encouraging and promoting common approaches globally to ensure that results exploit the opportunity to visualize global patterns and thus test global hypotheses. Each project pursues a goal that is an adaptation to its realm of the COML goals of assessment and explanation.

The field projects will discover new species and/or estimate abundance and distribution of known species. To go beyond assessing diversity to censusing where each species is distributed and how abundant each species may be requires use of standardized, internationally recognized protocols of sampling. The samples need to be validated and verified using scientifically accepted techniques. Given the vastness of the ocean and the scope of COML, all surveys will be under-sampling. Nonetheless, techniques should be "best practices" 


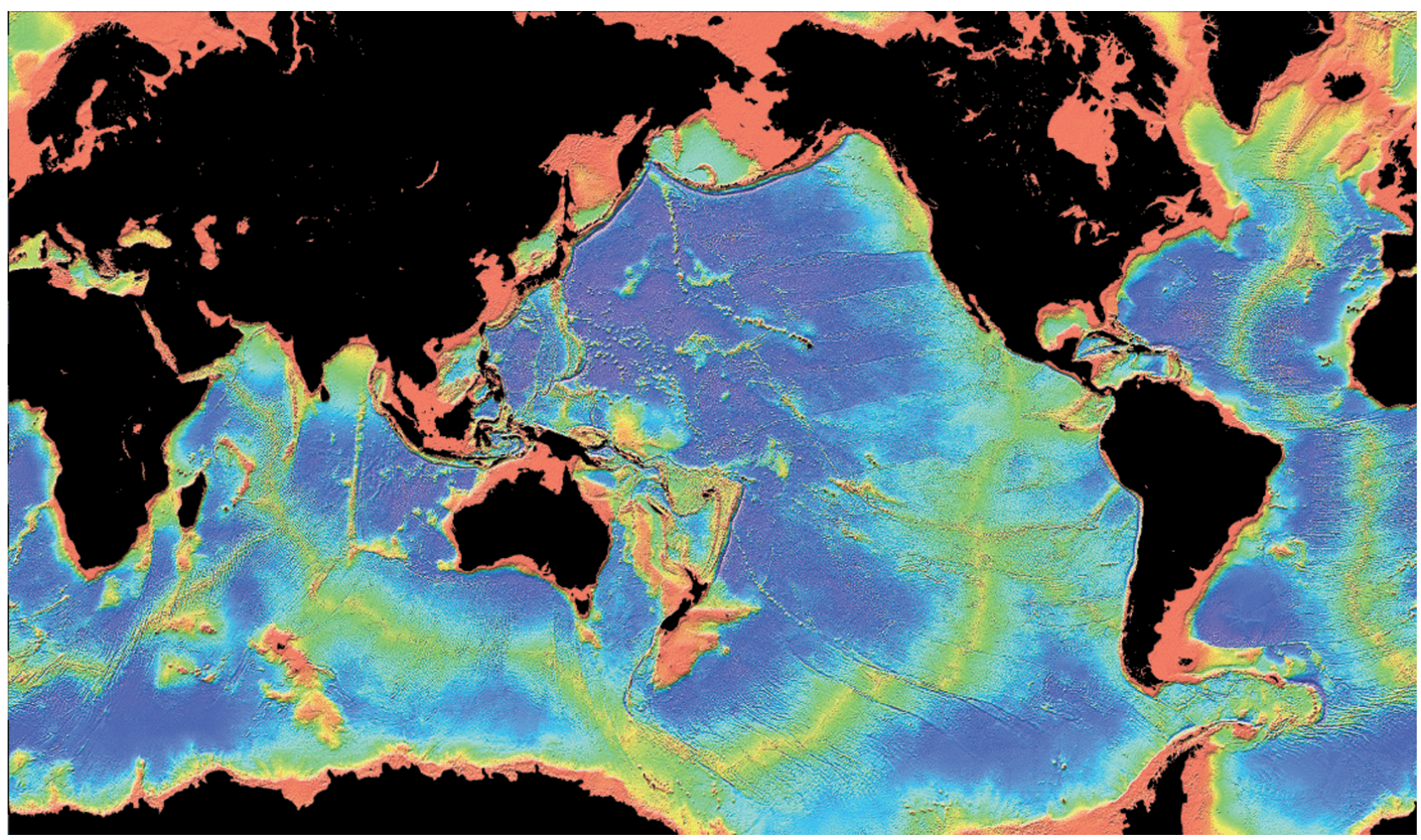

FIG. 2. - This map displays the bottom realms targeted by the projects, some still regional but many now nearly global - pink nearshore and coastal zones, yellow seamounts and geologically active ridges above blue abyssal plains. Other projects focus on the waters of light zones above and on the kilometers of mid-water depth. Image courtesy of W.H.F. Smith, NOAA (Smith and Sandwell, 1997).

for representing both the local and total populations using recognized statistical techniques. In using the baseline data to make projections, the assumptions and methodology used need to be identified, discussed, and shared widely and be consistent, linking local population estimates to independently produced global ocean populations estimates. Proper protocols are key to ensuring the legacy of COML as a foundation for future global assessments.
The field projects reflect the SSC's strategy of "known-unknown-unknowable" workshops. Identifying what is already known and what is unknowable with current technology allowed the workshops to design projects that apply efficient sampling over the largest possible scale while avoiding impossible pursuits. The projects and their principal investigators from more than 70 nations span the globe (Fig. 2) and explore all the realms and zones (Table 2).

TABLE 2. - Realms and zones, as defined by the COML, and their corresponding field projects. All project websites are accessible through the COML Portal, www.coml.org.

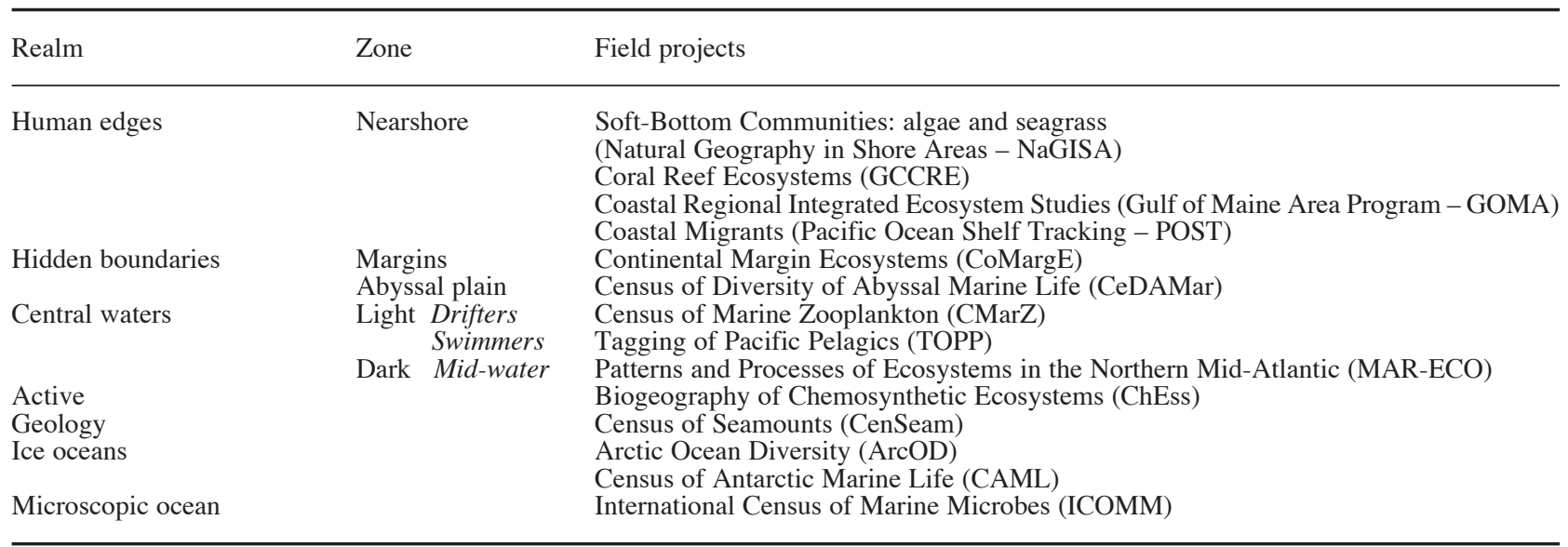




\section{The Future of Marine Animal Populations (FMAP)}

Censusing requires strategic sampling of the history and present state of the oceans. Next, prediction requires integration of the samplings of history and the present into models. Then coming full circle, attempting to model the future tests the adequacy of the sampling scheme. Modeling helps reveal what is known and how firmly, identify what may be unknown but knowable, and delimit what is likely to remain unknowable. Accordingly FMAP pursues goals of data exchange formats for easy model use, of survey designs, and of modeling the consequences of global fishing and climate change on marine life.

Five themes provide FMAP's tactics for reaching its goals: Statistical Design, Data Exchange and Model Interface, Model Development, Data Synthesis, and Prediction. Three centers on the Atlantic and Pacific make up FMAP. The center at Dalhousie University in Canada coordinates the service function of FMAP to the field projects, OBIS and HMAP in providing modeling and statistical advice, and linking to modelers to further the goals of the COML. Funds from the Pew Charitable Trust help demonstrate that models of the abundance, distribution, and population dynamics on a global scale are knowable in the important taxonomic group of sharks. The
Yokohama National University brings expertise in Fish Population Dynamics and linkage with the nearshore project on biodiversity gradients (NaGISA). The center at the University of Iceland has established an ambitious project to model entire communities of highly mobile marine organisms by incorporating high-tech biological tags that provide trajectories data on individuals, which will be useful for the tracking projects (POST and TOPP). Joint modeling workshops with the field projects develop efficient sampling strategies. FMAP logically extends time and space analyses of HMAP and OBIS.

\section{THE OCEAN BIOGEOGRAPHIC INFORMATION SYSTEM (OBIS)}

The infrastructure of an information seaway called OBIS constitutes COML's strategy for melding the data from COML's investigations and explorations and from other marine databases around the world. OBIS pursues the goal of a dynamic, global digital atlas for explanation of relations in the oceans with species, location and abundance, all integrated with environmental data, maps, and model outputs on the Internet.

OBIS begins with authoritative information contributed by experts about the location of species on a map of the oceans. OBIS further incorporates

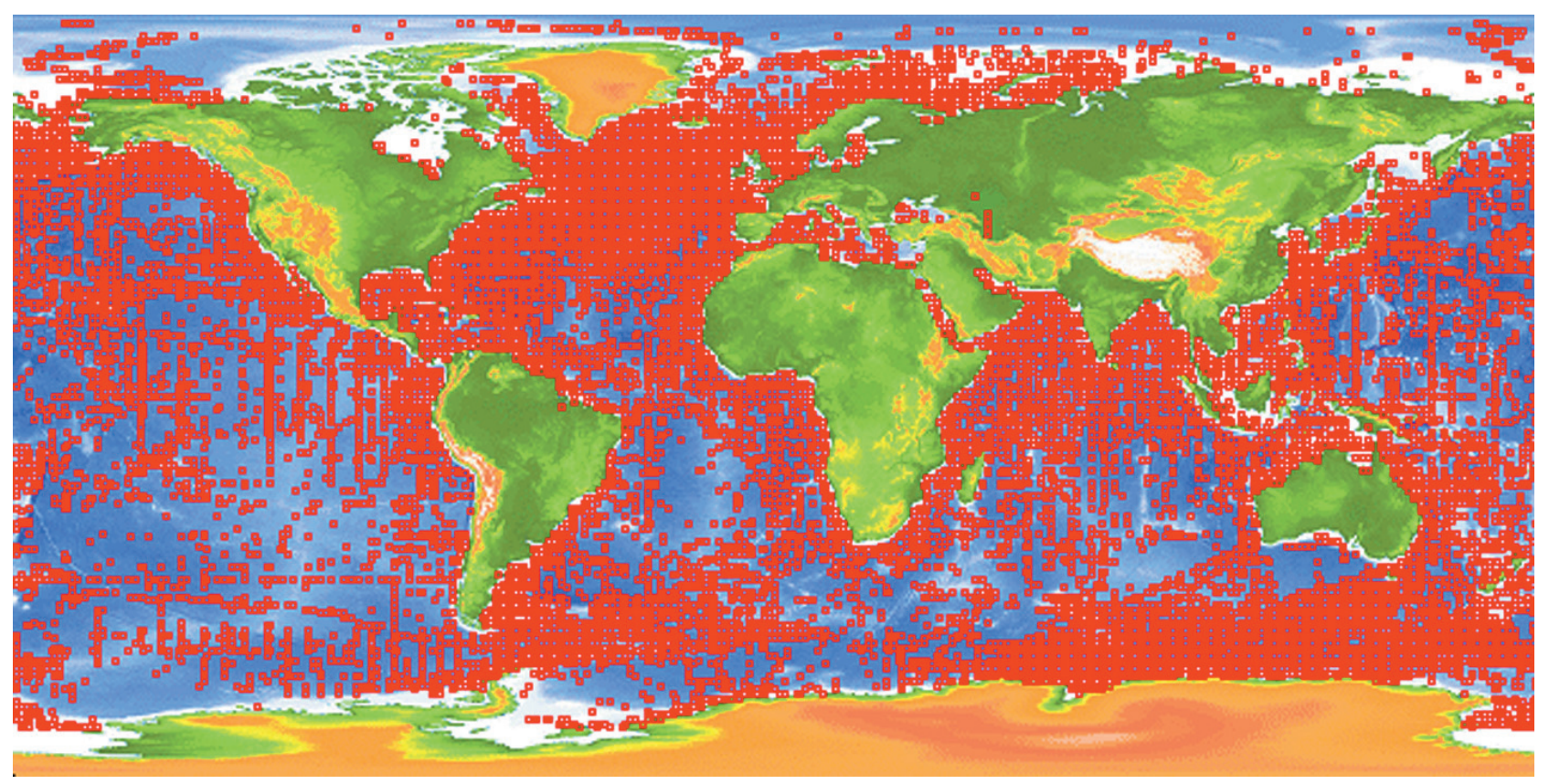

FIG. 3. - Horizontal spatial distribution of the locations for over 5 million data records for 40,000 known marine species in OBIS in 2004 (www.iobis.org). 
other geo-referenced species-level data sets such as the catches from continuous plankton recorders sampling along millions of kilometers, fisheries surveys and the world's natural history museums. OBIS also integrates data from environmental protection agencies to be used for environmental baselines. Databases accessible through the OBIS portal encompass the microscopic ZooGene, an international partnership to develop a zooplankton genomic barcode of DNA sequences for calanid copepods and euphausiids (Hebert et al., 2003; Stoeckle, 2003). They reach the largest sea creatures with SEAMAP (Spatial Ecological Analysis of Megavertebrate Populations) for the biogeography and ecology of whales, turtles, seabirds, and other large marine vertebrates worldwide. They include the physical environment with archives of oceanographic observations and products.

Both the Internet and the organization to take advantage of such opportunities can be considered new technologies that make the plethora of data more practical to analyze. In October 2004 OBIS passed the milestone of locating fully 40,000 species with 5 million records (Fig. 3). Everyone with a connection to the web can access the data. A visit to www.iobis.org shows the progress and promise of OBIS. At the portal enter, for example, the common name cod. The 417 matches begin with the Redflushed rock-cod (Aethaloperca rogaa). OBIS will draw a quick global map of the 60 collections of that cod and a deeper search reveals the catalog number and depository of the collections plus the author who named the species and date. (This species was named in 1775 !)

The OBIS International Committee includes members from Australia, Belgium, Canada, Germany, Japan, New Zealand, the United Kingdom, and the USA. The chair works in New Zealand, and the OBIS portal is directed at Rutgers University in New Jersey.

\section{GOVERNANCE}

After two years of feasibility workshops involving more than 300 scientists, a small group of senior marine scientists from around the world met in June 1999 and agreed to form a SSC to try to make the Census of Marine Life actually happen. The program assumed its basic contours at a meeting of the SSC at the Intergovernmental Oceanographic Commission (IOC) in Paris in early 2000. The SSC that governs the COML currently has members from Australia, Canada, Chile, Denmark, France, India, Japan, Malaysia, Netherlands, and USA. National or regional implementation committees range from Venezuela and Australia to Russia and Japan.

The COML has received and established cooperation with the all the main intergovernmental and nongovernmental international organizations and programs concerned with the oceans. Among its most valuable partners are the Global Biodiversity Information Facility (GBIF), IOC, the United Nations Food and Agriculture Organization (FAO), the United Nations Environmental Program (UNEP), World Conservation Monitoring Centre (WCMC), Global Ocean Observing System (GOOS), Scientific Committee on Oceanic Research (SCOR), DIVERSITAS, International Council for the Exploration of the Seas (ICES), North Pacific Marine Science Organization (PICES), International Association of Biological Oceanographers (IABO), and the International Union of Biological Sciences (IUBS).

Concepts and research priorities for projects are developed primarily through "known-unknownunknowable" workshops, a process that leads to the least globally redundant and most productive research approaches. The SSC has favored proposals with these characteristics: Potential to change present perspectives; Focus on species distributions; Known, unknown, unknowable context; Education and capacity building; At least regional in scope; Data available through OBIS; Novel technologies or applications; Able to contribute to 2010 report; Opportunities for discovery of new taxa; Complements existing projects.

\section{LEGACIES}

The most immediate legacy of the program will be the 2010 Census itself, an unprecedented assessment and explanation of the changing diversity, distribution, and abundance of marine species from the past to the present, and projection of future marine life. Realistically, of course, it will be what a coordinated and systematic census can attain within a decade. It will go beyond a search for unknown species to being a census, a Census of Marine Life encompassing the diversity of species, where each species lives and how abundant each species is. Interim or progress reports will be issued in 2005 and 2007 as well as annual highlights reports. Every 
project will of course post and publish many scientific reports offering detail in its field.

The COML is intended to produce three other legacies. One is the functioning information seaway about marine life, OBIS, whose utility will guarantee its continuity and growth. OBIS will prove an attractive and invaluable tool for management, education, and outreach as well as research. The next legacy is technology for observing marine life. COML is the test bed for many of the technologies and systems to form the biological components of the GOOS. Finally, COML should bequeath a set of international linkages that make future censuses of the global oceans much easier and more complete. The institutions and networks developed by COML, and the scientists apprenticed during all the COML projects, will strengthen marine science as a means of understanding change in the global component that is most vast.

\section{ACKNOWLEDGEMENTS}

Jesse Ausubel, Reginald Beach, Victor Gallardo, Fred Grassle, Dale Langford, Paul E. Waggoner

\section{REFERENCES}

Decker, C.J. and R. O'Dor. - 2002. A Census of marine life: unknowable or just unknown? Oceanol. Acta, 25: 179-186.

Hebert, P.D.N., A. Cywinska, S.L. Ball and J.R. deWaard. - 2003. Biological identifications through DNA barcodes. Proc. R. Soc. Lond. B, 270: 313-322.

O'Dor, R.K. - 2003. The Unknown Ocean: Baseline Report for the Census of Marine Life. CORE, Washington. (or www.coml.org).

O’Dor, R.K. - 2004. Viewpoint, a Census of Marine Life. BioScience 54(2): 2-3.

Smith, W.H.F. and D.T. Sandwell. - 1997. Global seafloor topography from satellite altimetry and ship depth soundings. Science, 277: 1956-1962.

Stoeckle, M. - 2003. Taxonomy, DNA, and the barcode of life. BioScience 53: 796-797. 